\title{
PRACE OŚRODKA ARCHIWÓW, BIBLIOTEK I MUZEÓW KOŚCIELNYCH W ZAKRESIE DOKUMENTOWANIA BIBLIOTEK KLASZTORNYCH
}

Ośrodek Archiwów Bibliotek i Muzeów Kościelnych powstał w 1956 r. początkowo jako dział Biblioteki Uniwersyteckiej KUL. Dopiero w 1959 r. uchwałą Senatu Akademickiego, Ośrodek ABMK został przekształcony w międzywydziałowy zakład uniwersytecki Katolickiego Uniwersytetu Lubelskiego, o charakterze naukowym i usługowym. Nadrzędnym celem Ośrodka jest gromadzenie i opracowywanie materiałów dla potrzeb zainteresowanych wydziałów i biblioteki KUL, oraz prowadzenie własnych badań naukowych. Zgodnie z postanowieniem Episkopatu Polski Ośrodek jest powołany jednocześnie do organizowania i sprawowania opieki metodyczno-naukowej nad archiwami, bibliotekami i muzeami kościelnymi, tak diecezjalnymi jak i zakonnymi w Polsce ${ }^{1}$.

Ośrodek ABMK realizuje swe zadania statutowe za pomocą różnorodnych sposobów. Prowadzi ewidencję i charakterystykę kościelnych zbiorów archiwalnych, bibliotecznych i muzealnych. Wspólnie z odpowiednimi katedrami opracowuje zebrane materiały. Nadto utrzymuje stałą łączność z archiwami, bibliotekami i muzeami kościelnymi oraz udziela im fachowej pomocy. Organizuje również szkolenie zawodowe pracowników archiwów, bibliotek i muzeów kościelnych. Bardzo ważną działalnością Ośrodka ABMK jest reprodukowanie, mikrofilmowanie $\mathrm{i}$ fotografowanie cenniejszych i potrzebniejszych dla badań naukowych przedmiotów archiwalnych, bibliograficznych i muzealnych ${ }^{2}$.

* Artur Hamryszczak - mgr historii, asystent naukowy w Ośrodku Archiwów Bibliotek i Muzeów Kościelnych KUL.

${ }^{1}$ Statut Ośrodka Archiwów, Bibliotek i Muzeów Kościelnych przy Katolickim Uniwersytecie Lubelskim, Lublin 1960, s. 3. Zob. też. M. Dębowska, Ośrodek Archiwów, Bibliotek i Muzeów Kościelnych katolickiego Uniwersytetu Lubelskiego Jana Pawła II 1956-2006, Lublin 2006, s. 204-206 (Aneks IV). Decyzją Senatu Akademickiego KUL z dnia 17 marca 2006 r. wszystkie zakłady, ośrodki i instytuty międzywydziałowe uczelni od 1 września 2006 r. zostały przekształcone w instytuty naukowo-badawcze. Ośrodek ABMK zmienił nazwę na Instytut Archiwów Bibliotek i Muzeów Kościelnych. Od 1 pażdziernika 2009 r. Instytut ABMK został włączony w struktury Wydziału Teologii KU1 i wrócił do swej dawnej nazwy: Ośrodek Archiwów Bibliotek i Muzeów Kościelnych.

${ }^{2}$ Statut Ośrodka Archiwów, Bibliotek i Muzeów Kościelnych, s. 3-4. 
Akcja mikrofilmowania najcenniejszych archiwaliów i zbiorów bibliotecznych zaczęła się w 1960 r. W zamyśle założycieli, w Ośrodku ABMK miało powstać centralne mikrofilmowe archiwum kościelne, obejmujące archiwalia ważniejszych archiwów kościelnych i państwowych (dotyczących Kościoła katolickiego) z okresu Polski przedrozbiorowej do $1795 \mathrm{r}^{3}$. Najczęściej mikrofilmowano materiały archiwalne, natomiast zbiory biblioteczne (najczęściej muzykalia) tylko sporadycznie. Niestety Ośrodek ABMK nie posiadał, i nadal nie posiada programu kompleksowego mikrofilmowania zbiorów bibliotecznych. Sytuacja taka wynika z kilku przyczyn. Jedna z najważniejszych jest kłopot z uzyskaniem zgody na taką działalność dokumentacyjną Ośrodka ABMK ze strony władz bibliotek klasztornych. Często jest to spowodowane brakiem inwentaryzacji księgozbioru lub niewyodrębnieniem zbiorów bibliotecznych ze struktury archiwum danego klasztoru. Niekiedy wszystkie zbiory książkowe traktowane są jako archiwalia, zaś w sytuacji niefachowego opracowania biblioteki, książki rękopiśmienne zaliczano do materiałów archiwalnych. Uważano bowiem, że do biblioteki można zaliczyć tylko drukowane woluminy ${ }^{4}$.

Dotychczas Ośrodek ABMK zmikrofilmował najcenniejsze obiekty z następujących księgozbiorów bibliotecznych: Paulinów na Jasnej Górze, Cystersów w Mogile, Karmelitanek Bosych w Krakowie, Klarysek w Krakowie i w Starym Sączu, Wizytek w Krakowie, Benedyktynów w Tyńcu, Benedyktynek w Przemyślu i Staniątkach, Bożogrobców w Miechowie oraz Norbertanek w Imbramowicach.

Z biblioteki Paulinów na Jasnej Górze zmikrofilmowano osiem piętnastowiecznych rękopiśmiennych homiliarzy i kazań (homiliae et sermones), brewiarzy (Breviarum Romanum), mszałów (Missale Ordinis S. Pauli I Eremita in Polonia), objaśnień Pisma Św. (Testamentum vetus et novum; Życie Pana Jezusa z obszernym wykładem moralnym cz. II) $)^{5}$.

Biblioteka Cystersów w Mogile użyczyła do zmikrofilmowania pięć rękopisów muzycznych z XVIII wieku (Pastorella i Pastoritia) ${ }^{6}$.

Do znaczącego księgozbioru zmikrofilmowanego przez Ośrodek ABMK należy zaliczyć bibliotekę Karmelitanek Bosych z Krakowa. Zmikrofilmowano muzykalia pochodzące od XVII do XIX wieku, głównie zbiory kolęd i pastorałek, pieśni religijnych na różne okazje oraz kancjonały i kantyczki ${ }^{7}$. Warto wspomnieć, że w zasobach Ośrodka ABMK znajduje się zmikrofilmowany prawie cały zbiór muzyczny z krakowskiego klasztoru karmelitańskiego.

Biblioteka Klarysek w Krakowie dostarczyła pięć XVII-XIX wiecznych mu-

${ }^{3}$ B. Kumor, Mikrofilmowanie zbiorów kościelnych przez Ośrodek Archiwów Bibliotek i Muzeów Kościelnych, „Archiwa Biblioteki i Muzea Kościelne” (dalej: ABMK), 40 (1980), s. 119-122; Dębowska, Ośrodek Archiwów, Bibliotek i Muzeów Kościelnych, s. 117-118.

${ }^{4}$ Szerzej o problemie pisze S. Librowski, Archiwa, Biblioteki i Muzea Kościelne. Podobieństwa i różnice. Próba rozgraniczenia, ABMK, 16 (1968) s. 5-18.

${ }^{5}$ B. Kumor, Katalog mikrofilmów Ośrodka Archiwów, Bibliotek i Muzeów Kościelnych przy Katolickim Uniwersytecie Lubelskim. Nr 4, ABMK, 31 (1975) s. 74.

${ }^{6}$ Tamże, s. 367.

${ }^{7}$ Tamże, s. 367-369. 
zykaliów-zbiory kolęd i pastorałek w języku polskim (Wesołe koncerty zrodzonemu Jezusowi, Zabawa przy nowo narodzonym Chrystusie) oraz akompaniament do pieśni kościelnych ${ }^{8}$.

Siostry Wizytki z Krakowa udostępniły do zmikrofilmowania dwie pozycje z XVIII w.: wiersze (Łoże krzyża), modlitwy (Hymny na caly rok) oraz XVII wieczny zbiór pieśni łacińskich i polskich (Cornu Copie seu varietes copiosa) ${ }^{9}$.

$\mathrm{Z}$ archiwum Sióstr Klarysek ze Starego Sącza zmikrofilmowano m.in. pamiętniki-kroniki konwentu z XVII-XIX w. ${ }^{10}$

Biblioteka Opactwa św. Wojciecha PP Benedyktynek w Staniątkach udostępniła zbiory muzyczne z XVI-XVIII wieku. Jest to 11 kancjonałów z nutami (najstarsze z $1586 \mathrm{r}$. $)^{11}$.

Biblioteka Arcyopactwa Benedyktynów z Tyńca przekazała ze swych zbiorów do zmikrofilmowania dwa starodruki z XVII wieku (Tinetia seu historia monasterii Tinecensis ordinis S. Benedicti; Aquila Polono-Benedictina ordinis D. P. Benedicti per Polonam $)^{12}$.

Ze zbiorów Benedyktynek w Przemyślu zmikrofilmowano muzykalia XVIIXIX wieku. Są to antyfonarze $(1617,1630,1645)$, graduały (1600), księgi organistów i zbiory pieśni religijnych na różne święta ${ }^{13}$.

Wyżej wymienione zbiory biblioteczne nie zostały jednak całkowicie opracowane i zmikrofilmowane przez Ośrodek ABMK. Nie wiadomo jakie kryteria decydowały o wyborze poszczególnych pozycji bibliotecznych do opracowania i zmikrofilmowania. Niestety, jak można zauważyć, proces mikrofilmowania objął tylko kilka bibliotek klasztornych. Zbiory muzyczne powierzane Ośrodkowi ABMK były fachowo opracowywane przez profesorów z Instytutu Muzykologii KUL, którzy częstokroć sami dostarczali opisane muzykalia z prośbą o zmikrofilmowanie ${ }^{14}$.

Na przełomie XX i XXI wieku pracownicy Ośrodka ABMK dokonali całościowej inwentaryzacji i spisu dwóch bibliotek klasztornych: Bożogrobców w Miechowie i Norbertanek w Imbramowicach.

Biblioteka Bożogrobców w Miechowie ${ }^{15}$ została w latach 1994-1999 zinwen-

${ }^{8}$ Tamże, s. 369-370.

${ }^{9}$ Tamże, s. 370.

${ }^{10}$ Tamże, s. 371.

${ }^{11}$ B. Kumor, Katalog mikrofilmów Ośrodka Archiwów, Bibliotek i Muzeów Kościelnych przy Katolickim Uniwersytecie Lubelskim. Nr 2, ABMK, 31 (1975) s. 255-257.

${ }^{12}$ Tamże, s. 254.

${ }^{13}$ M. Dębowska, Katalog mikrofilmów Osrodka Archiwów Bibliotek i Muzeów Kościelnych przy Katolickim Uniwerstytecie Lubelskim. Nr 6, ABMK, 67 (1997) s. 211-212.

${ }^{14}$ Ośrodek ABMK zawdzięcza dużo ks. prof. Ireneuszowi Pawlakowi, który opracował muzykalia norbertańskie z Imbramowic.

${ }^{15}$ Więcej o historii biblioteki bożogrobców w Miechowie czyt. R. Skrzyniarz, Księgozbiór historyczny Bożogrobców w parafii Miechów, ABMK, 77 (2002) s. 71-76; tenże, Początki archiwum zakonnego bożogrobców w Miechowie, ABMK, 71 (1999) s. 408; Z. Pęckowski, Księgozbiór bożogrobców miechowskich i inwentaryzacja jego pozostatości w Miechowie, Miechów 1978-1979, mps. 
taryzowana przez dr hab. Ryszarda Skrzyniarza ${ }^{16}$. Poprzednio dokonał tego w latach 70. XX w. Zbigniew Pęckowski. Podał on wówczas informację, że biblioteka liczy 665 woluminów, a w tym 147 dubletów. Po inwentaryzacji dokonanej przez Ryszarda Skrzyniarza okazało się, że aktualnie w Miechowie znajduje się 660 woluminów, ponieważ wyłączono dwie księgi brackie (są one zbiorami archiwalnymi), natomiast brakuje trzech woluminów. Odnaleziono natomiast dwie książki z XVIII w. i pięć rękopisów z XIX w., o których jednak trudno powiedzieć, że należały do biblioteki bożogrobców. Dodatkowo razem z księgozbiorem bożogrobców znajduje się około 250 woluminów wydanych po 1819 roku $^{17}$. Zachowane w bibliotece miechowskiej księgi pochodzą prawdopodobnie od XV do XIX wieku. Cztery z nich to prawdopodobnie inkunabuły z końca XV w. Z XVI w. pochodzi 175 woluminów, z XVII w. 267, a z XVIII w. jest ich 175, zaś z XIX w (do 1819 r.) jest 15 ksiąg. W stosunku do 29 woluminów nie ustalono daty wydania, gdyż brak jest kart początkowych. W zachowanym księgozbiorze jest 59 ksiąg $\mathrm{w}$ języku polskim, $6 \mathrm{w}$ języku niemieckim, zaś pozostałe $\mathrm{w}$ języku łacińskim. Treść ksiąg stanowią kazania - ponad połowę zachowanych ksiąg, dzieła teologiczne, traktaty, komentarze, podręczniki, brewiarze, żywoty świętych i Biblie. Na niektórych z tych ksiąg - szczególnie z kazaniami - znajdują się glosy świadczące o korzystaniu z tych pozycji ${ }^{18}$.

Szczególnie cenna współpraca między Ośrodkiem ABMK a klasztorem Norbertanek w Imbramowicach została nawiązana w $1998 \mathrm{r}$. i trwa do dnia dzisiejsze$\mathrm{go}^{19}$. Jest to o tyle istotna inicjatywa, że siostry udostępniły całość swoich zbiorów archiwalnych, bibliotecznych i muzealnych do fachowego opracowania. Warto wspomnieć, że klasztor ten założony w1226 r. nie uległ kasacie w okresie zaborów. Nawet $\mathrm{w}$ czasie różnych zawieruch wojennych nie był zdewastowany. Jedynie kilkukrotne pożary wyrządziły klasztorowi duże szkody. Dotychczas cały zasób kulturowy nie był znany szerszemu gronu badaczy. Spowodowane było to nieuporządkowaniem zbiorów i brakiem katalogów. Dodatkowo w klasztorze obowiązuje ścisła klauzura papieska, która uniemożliwia swobodny dostęp badaczy do zbiorów kulturowych ${ }^{20}$.

Starodruki z biblioteki klasztornej skatalogował ks. dr hab. Włodzimierz Bie-

${ }^{16}$ Skrzyniarz, Księgozbiór historyczny Bożogrobców, s.76.

${ }^{17}$ Tamże, s. 75.

${ }^{18}$ Tamże s. 76.

${ }^{19}$ Ksieni Norbertanek w Imbramowicach, m. Antonia Irena Zaczyńska zwróciła się listem datowanym na 24 II 1998 r. do kierownictwa Ośrodka ABMK z prośbą, aby pomóc siostrom w opracowaniu zbiorów kulturowych, które znajdowały się w klasztorze. W. Żurek, Wspótpraca Instytutu Archiwów Bibliotek i Muzeów Kościelnych Katolickiego Uniwersytetu Lubelskiego Jana Pawła II z klasztorem sióstr norbertanek w Imbramowicach, ABMK, 95 (2011) s. 375; tenże, Ośrodek Archiwów Bibliotek i Muzeów Kościelnych Katolickiego Uniwersytetu Lubelskiego Jana Pawła II w mijającym pótwieczu, ABMK, 86 (2006), s. 80.

${ }^{20}$ Żurek, Ośrodek Archiwów Bibliotek i Muzeów Kościelnych, s. 79; A. Hamryszczak, Ochrona kościelnych dóbr kultury na przykładzie klasztoru norbertanek w Imbramowicach, w: Między teoria a praktyka. Ochrona w małych bibliotekach i archiwach, red. A. Czajka, R. Lis, Cieszyn 2010, s. 348. 
lak. Po sporządzeniu kart bibliotecznych udostępnił je Bibliotece Narodowej w Warszawie, która prowadzi centralny rejestr starodruków. Księgozbiór starodruków imbramowickich liczy około 780 pozycji, głównie z XVII i XVIII wieku. Jednak wspomniana liczba nie jest ostateczna. Niestety, gdy udało się uzyskać bezpośredni dostęp do klasztoru, okazało się, że została pominięta znaczna liczba książek. Wynikało to $\mathrm{z}$ faktu zaliczenia przez siostry niektórych książek do dubletów. Dodatkowo siostry nie poinformowały pracowników ABMK o istnieniu takich książek. Dotyczy to około 115 woluminów, nie licząc tych, które zaliczono do ksiąg rękopiśmiennych, które zostały oprawione wspólnie z rękopisami ${ }^{21}$.

W imbramowickim księgozbiorze starodruków ponad połowę stanowią dzieła $\mathrm{z}$ ascetyki, medytacji i nabożeństw. Licznie reprezentowane są również żywoty świętych oraz pozycje o historii zakonu norbertańskiego. Pośród starodruków znaleziono również cztery pozycje, zaliczane do tzw. „białych kruków”. Jest to m.in. pierwsze wydanie w języku polskim rozważań drogi krzyżowej22.

Kilka najcenniejszych woluminów z imbramowickiej biblioteki, zostało zmikrofilmowanych w Ośrodku ABMK. Są to rękopisy muzyczne zawierające śpiewy gregoriańskie wraz z zapisem nutowym. Wśród nich najcenniejsze są: antyfonarz z początku XIII w. (składający się z dwóch części) oraz graduał pochodzący z 1343 r., z licznymi iluminacjami. Woluminy te zostały nie tylko fachowo opracowane i zmikrofilmowane w Ośrodku ABMK, ale też poddano je renowacji w Pracowni Konserwacji Biblioteki Uniwersyteckiej KUL ${ }^{23}$. Do innych równie cennych książek, które zostały zmikrofilmowane należą: antyfonarze XVII-XIX w., rytuały z XVIII w., śpiewniki pieśni religijnych na różne okazje z XVII-XVIII wieku ${ }^{24}$. Ogółem zmikrofilmowano 40 różnego rodzaju pozycji z imbramowickiej biblioteki klasztornej ${ }^{25}$.

Ośrodek ABMK oprócz zabezpieczania bibliotecznych zbiorów klasztornych przez akcję ich opracowywania i mikrofilmowania, prowadzi też zgodnie ze swym statutem ${ }^{26}$, działalność szkoleniową poprzez organizowanie w cyklu trzyletnim sympozjów poświęconym kolejno archiwom, bibliotekom i muzeom kościelnym.

Niestety nigdy nie odbyło się sympozjum poświęcone wyłącznie bibliotekom klasztornym. W dniach 24-25 września 2001 r. Ośrodek zorganizował zjazd w którym tematyka księgozbiorów klasztornych była tylko jednym z poruszanych zagadnień Tytuł sesji to: Problemy bibliotek parafialnych i klasztornych. Na posiedzeniach poruszono zagadnienia komputeryzacji bibliotek klasztornych (s. Elżbieta A. Janisz, Komputeryzacja biblioteki klasztoru OO Karmelitów Bosych w Czernej w ramach wspótpracy z Federacją Bibliotek Kościelnych FIDES), sta-

${ }^{21}$ W. Bielak, Księgozbiór Panien Norbertanek w Imbramowicach, ABMK, 95 (2011) s. 7.

${ }^{22}$ Tamże, s. 8.

${ }^{23}$ Hamryszczak, Ochrona kościelnych dóbr kultury na przykładzie klasztoru norbertanek $w$ Imbramowicach, s. 350-354.

${ }^{24}$ M. Dębowska, Katalog mikrofilmów Ośrodka Archiwów, Bibliotek i Muzeów Kościelnych Katolickiego Uniwersytetu Lubelskiego Nr 7, ABMK, 84 (2005) s.58-62.

${ }^{25}$ Tamże.

${ }^{26}$ Statut Ośrodka, s. 4. 
rodruków (Joanna Kozińska, Zbiory starych książek w bibliotekach parafialnych i klasztornych), funkcjami bibliotek parafialnych i klasztornych (Marek T. Zahajkiewicz, Funkcja i znaczenie biblioteki parafialnej lub klasztornej), warunkach przechowywania księgozbioru (Jolanta Wasilewska, Warunki przechowywania i ochrona księgozbioru bibliotecznego), księgozbiorom klasztornym w Miechowie (Ryszard Skrzyniarz, Księgozbiór historyczny bożogrobców w parafii Miechów) i kapucynów w Lublinie (Roland Prejs, Biblioteka klasztoru Kapucynów w Lublinie. Przyktad biblioteki zakonnej $)^{27}$.

W 2004 r. w dniach 28-29 września zorganizowano sympozjum Funkcje $i$ zadania bibliotek kościelnych. Problem bibliotek klasztornych zawarty był w wygłoszonych referatach, jako jedno z ich zagadnień. Na sesji wygłoszono następujące referaty: ks. M. Zahajkiewicz, Miejsce bibliotek kościelnych w kulturze. Wprowadzenie do sympozjum, ks. F. Greniuk, Biblioteki kościelne w misji Kościoła; ks. W. Graczyk, Kulturowo-religijna rola bibliotek kościelnych; ks. bp M. Leszczyński, Biblioteki kościelne w najnowszych wypowiedziach Papieskiej Komisji ds. Kościelnych Dóbr Kultury; ks. W. Żurek, Stan bibliotek kościelnych w Polsce, J. Kwaśniewska-Powroźnik, Katalog centralny i inne systemy wyszukiwawcze. Wprowadzenie od strony użytkownika; I. Kasiura, U. Szymańska, Pierwsza pomoc dla ksiażki; J. Wasilewska, Chora ksiązka; B. Skoczyńska, Niebezpieczna ksiązka; A. Wałkówski, Biblioteka klasztorna jako miejsce pracy średniowiecznego uczonego. Rozważania na tle badań piśmiennictwa; P. Błażewicz, $Z$ badań nad inkunabułami Biblioteki Kolegiackiej w Dobrym Mieście; ks. J. Latawiec, Dokument elektroniczny w bibliotece oraz G.M. Wilczyńska, NUKAT a katalog lokalny ${ }^{28}$.

Następne sympozjum poświęcone kościelnym zbiorom bibliotecznym Ośrodek ABMK zorganizował 24 września 2008 r. Tytuł sesji brzmiał: Kościelne zbiory biblioteczne. dziedzictwo przeszłości i wspótczesne wyzwania. Problem księgozbiorów klasztornych był jednym z poruszanych zagadnień. Podczas obrad przedstawiono następujące referaty: ks. J. Bednarczyk, Biblioteki kościelne w stużbie ewangelizacji; ks. K. Gonet, To już 17 lat! Przeszłość i plany na przyszłość Federacji Bibliotek Kościelnych FIDES; ks. W. Graczyk, Zachowane szczatki księgozbiorów po skasowanych $w$ XIX wieku klasztorach $w$ diecezji płockiej w obecnych zbiorach Biblioteki Wyższego Seminarium Duchownego w Ptocku; I. Kasiura, Tajemnice opraw ksiażkowych na podstawie odkryć dokonanych podczas prac konserwatorskich w Bibliotece Uniwersyteckiej KUL; J.M. Marszalska, Dramatyczne losy ksieggozbiorów kościelnych w południowych guberniach Królestwa Polskiego w XIX wieku w świetle obecnego zasobu starych druków Biblioteki WSD w Ptocku; ks. T. Moskal, Biblioteki kolegiackie w diecezji krakowskiej w okresie przedrozbiorowym; J. Wasilewska, Pamiątka - świętość czy talizman? Dlaczego zbieramy obrazki święte?; E. Warda, Skryptorium podstawa bibliotek oraz ks. H. Witczak, Księgozbiory kościelne w polskich bibliotekach cyfrowych ${ }^{29}$.

Do ważnego przedsięwzięcia Ośrodka ABMK należy zaliczyć zorganizowanie w dniach 4-8 lipca 1960 r. kursu inwentaryzacji rękopisów średniowiecznych.

\footnotetext{
${ }^{27}$ Wygłoszone na sympozjum referaty zamieszczono w tomie 77 (2002) ABMK, s. 9-115.

${ }^{28}$ Wygłoszone na sympozjum referaty zamieszczono w tomie 83 (2005) ABMK, s. 5-192.

${ }^{29}$ Wygłoszone na sympozjum referatyzamieszczono w tomie 91 (2009) ABMK, s. 5-102.
} 
Kurs taki był podyktowany koniecznością wyszkolenia fachowych pracowników do inwentaryzacji rękopisów przechowywanych w zbiorach Kościoła katolickie$\mathrm{go}^{30}$. Inicjatywa spisu wszystkich średniowiecznych rękopisów literackich do 1550 r. na terenie Polski, wyszła z Instytutu Badań Literackich Polskiej Akademii Nauk. Ośrodek ABMK był koordynatorem prac rejestracyjnych w instytucjach kościelnych. Do współpracy z Ośrodkiem ABMK w akcji rejestracji rękopisów literackich powołano delegatów z poszczególnych diecezji oraz zakonów męskich i żeńskich. Zdecydowano, że w zbiorach kościelnych będą sporządzane spisy rękopisów powstałe do $1750 \mathrm{roku}^{31}$.

Na kursie opisu rękopisów wykładowcami byli specjaliści z różnych ośrodków naukowych Krakowa, Poznania, Warszawy i Wrocławia. Omówili oni zagadnienia z zakresu: paleografii łacińskiej i chronologii średniowiecznej (Brygida Kürbisówna), materiału rękopisów (Stanisław Żurowski), zdobnictwa rękopisów (Stanisława Sawicka), adnotacji muzycznych (Jerzy Woronczak), oprawy rękopisów (Helena Szwejkowska), konserwacji rękopisów (Irena Sadurska). Poszczególne kategorie rękopisów średniowiecznych zaprezentowali: Jerzy Worończak - rękopisy biblijne, Henryk Kowalewicz - rękopisy hagiograficzne i historyczne, Jerzy Zathey - rękopisy filozoficzne. Julian Lewański omówił przepisy katalogowania i sposób wypełniania kart inwentaryzacyjnych. W kursie wzięli udział pracownicy archiwów, bibliotek i muzeów kościelnych oraz wykładowcy seminariów duchownych. Okazało się, że tylko nieliczna grupa uczestników kursu spotkała się po raz pierwszy z zagadnieniem rękopisów średniowiecznych. Dodatkowym uzupełnieniem zagadnień podejmowanych w trakcie trwania kursu, stała się Wystawa o rękopisach zorganizowana przez pracowników Biblioteki Uniwersyteckiej KUL, w której budynku odbywały się zajęcia ${ }^{32}$.

Organem wydawniczym Ośrodka ABMK jest półrocznik Archiwa Biblioteki i Muzea Kościelne, który ukazuje się od 1959 r. Na łamach czasopisma, zgodnie $\mathrm{z}$ jego profilem publikowane są artykuły naukowe dotyczące m.in. klasztornych zbiorów bibliotecznych ${ }^{33}$.

W czasopiśmie dotychczas ukazały się katalogi bibliotek klasztornych Kapu-

${ }^{30}$ Archiwum Ośrodka Archiwó Bibliotek i Muzeów Kościelnych (dalej: ArOABMK), t. Rejestracja rękopisów średniowiecznych, Protokół zebrania w sprawie rejestracji rękopisów średniowiecznych dnia 25 I 1960 w Instytucie badań Literackich PAN

${ }^{31}$ ArOABMK, t. Rejestracja rękopisów średniowiecznych, Protokół zebrania w sprawie rejestracji rękopisów średniowiecznych dnia 25 I 1960 w Instytucie badań Literackich PAN.

${ }^{32}$ B. Kumor, Sprawozdane z kursu dla pracowników inwentaryzacji średniowiecznych rękopisów bibliotecznych, zorganizowanego przez Ośrodek Archiwów, Bibliotek i Muzeów Kościelnych w dniach od 4 do 8 lipca 1960 r., ABMK, 2 (1961) z. 1/2 s. 283-288.

${ }_{33}$ Statut Ośrodka, s. 4; A. Hamryszczak, Pótrocznik „Archiwa Biblioteki i Muzea Kościelne” (1959-2010), w: Czasopisma naukowe bibliotek, archiwów, muzeów, red. A. Królczyk, Kórnik 2010, s.164; M . Dębowska, Wkład księdza profesora Stanisława Librowskiego w powstanie, organizacje i realizację zadań statutowych Ośrodka Archiwów Bibliotek i Muzeów Kościelnych, „Studia Włocławskie", 10 (2007), s. 53-61. 
cynów $^{34}$, Jezuitów ${ }^{35}$, Cystersów w Szczyrzycu ${ }^{36}$, Benedyktynek w Staniątkach ${ }^{37}$ i Przemyślu ${ }^{38}$, Bernardynów ${ }^{39}$ oraz Cysterek-benedyktynek z Torunia ${ }^{40}$.

Ponadto regularnie publikowane są na łamach ABMK monografie poświęcone poszczególnym książnicom klasztornym: Karmelitów Bosych w Czernej ${ }^{41}$ i w Kcyni ${ }^{42}$, Cystersów w Szczyrzycu ${ }^{43}$, polskiej prowincji Werbistów ${ }^{44}$, Jezuitów warszawskich ${ }^{45}$, Franciszkanów - Reformatów w Łąkach na Pomorzu ${ }^{46}$, Dominikanów w Krakowie ${ }^{47}$, Zakonu Ducha Świętego ${ }^{48}$, Marianów w Puszczy Kora-

${ }^{34}$ Katalog obejmuje spis rękopisów kapucyńskich klasztorów w Krakowie, Krośnie, Rozwadowie, Sędziszowie. K. Gadacz, Katalog rękopisów bibliotecznych Prowincji Krakowskiej zakonu OO Kapucynów, ABMK, 7 (1963) s. 95-272.

${ }^{35}$ L. Grzebień, Katalog starych druków Biblioteki Teologicznej Bobolanum «Polonica XVI w.», ABMK, 16 (1968) s. 243-278. tenże, Uzupetnienia do Bibliografii Estreicherów z Biblioteki Teologicznej Bobolanum w Warszawie «katalog», ABMK, 19 (1969) s. 45-80.

${ }^{36}$ R. Nir, Rękopisy muzyczne w Bibliotece OO Cystersów w Szczyrzycu «katalog», ABMK, 37 (1978) s. 233-248.

${ }^{37}$ W. Świerczek, Katalog kancjonałów staniąteckich i pieśni, ABMK, 41 (1980) s. 127-189.

${ }^{38}$ J. Jabłonkowska, Rękopisy biblioteki sióstr benedyktynek w Przemyślu, ABMK, 74 (2000) s. 65-144.

${ }^{39}$ E. Lenart, Katalog bernardyńskich rękopisów liturgicznych w Polsce od XV do XVIII wieku, ABMK, 53 (1986) s. 103-274.

${ }^{40} \mathrm{~J}$. Kurek, Inwentarz zespotu akt cysterek-benedyktynek toruńskich z lata 1311-1833, ABMK, 86 (2007) s. 189-285.

${ }^{41}$ J. Długosz, Biblioteka klasztoru OO Karmelitów Bosych w Czernej, ABMK, 11 (1965) s. 109-117; J.M. Marszalska, Inwentarze ksiag biblioteki karmelitów bosych w Czernej jako przejaw systematyzacji zbiorów klasztornych w XVIII i XIX wieku, ABMK, s. 263-274.

${ }^{42}$ A. Szudrowicz, Biblioteka klasztoru karmelitów w Kcyni, ABMK, 78 (2002) s. 243-274.

${ }^{43}$ W. Graczyk, Kilka uwag w sprawie rzekomego wywiezienia części zbiorów biblioteki cystersów w Szczyrzycu do Lwowa, Tarnowa czy innych bibliotek, ABMK, 90 (2008) s. 41-47; J.M. Marszalska, Pierwszy inwentarz ksiąg klasztoru cystersów w Szczyrzycu sporządzony za rządów profesa pelplińskiego a następnie opata w Szczyrzycu Floriana Andrzeja Gotartowskiego (17531766), ABMK, 90 (2008), s. 91-97.

${ }^{44}$ B. Konieczka, Zbiory biblioteczne Polskiej Prowincji Zgromadzenia Stowa Bożego (Werbistów), ABMK, 37 (1978) s. 267-270.

${ }^{45}$ R. Nir, Biblioteka Pisarzy Towarzystwa Jezusowego w Warszawie ABMK, 34 (1977) s. 175180.

${ }^{46}$ E. Piszcz, Biblioteka klasztoru oo Reformatów w Eakach na Pomorzu, ABMK, 2 (1961) z. $1 / 2$, s. 207-226.

${ }^{47}$ R. Świętochowski, Biblioteka oo Dominikanów w Krakowie, ABMK, 33 (1976) s. 299-311.

${ }^{48}$ K. Antosiewicz, Biblioteki Zakonu Ducha Świętego w Polsce, ABMK, 41 (1980) s. 351-400. 
biowskiej $^{49}$, Bożogrobców nyskich ${ }^{50}$ i miechowskich ${ }^{51}$, Paulinów jasnogórskich ${ }^{52}$, Bernardynów radomskich ${ }^{53}$ i lwowskich ${ }^{54}$, Klarysek krakowskich ${ }^{55}$, Benedyktynek ze Staniątek ${ }^{56}$ oraz Benedyktynów ${ }^{57}$.

Na łamach półrocznika publikuje się również artykuły będące fachową pomocą dla bibliotekarzy kościelnych ${ }^{58}$.

Ponadto w czasopiśmie ABMK ukazują się sprawozdania z sympozjów organizowanych przez Ośrodek ABMK, ale również innych kursów poświęconych szeroko rozumianej tematyce bibliotekarstwa kościelnego ${ }^{59}$. Oczywiście na łamach tego czasopisma sukcesywnie ukazują się kolejne katalogi mikrofilmów wykonanych w Ośrodku ABMK ${ }^{60}$. Najnowszy nr 7 katalogu został wydrukowany

${ }^{49}$ W. Karpuk, Biblioteka Marianów w Puszczy Korabiewskiej (Mariańskiej) na podstawie inwentarza z 1845 roku, ABMK, 69 (1998) s. 171-398.

${ }^{50}$ K. Dola, Rękopisy bożogrobców nyskich (śląskich) z ostatniej ćwierci XVII wieku, ABMK, 61 (1992) s. 51-82.

${ }^{51}$ R. Skrzyniarz, Księgozbiór historyczny Bożogrobców w parafii Miechów, ABMK, 77 (2002) s. 77-80; E. Truskolaska, Księgozbiór bożogrobców miechowskich w Bibliotece Uniwersyteckiej w Warszawie, ABMK, 81 (2004) s. 353-369.

${ }^{52}$ A. Bajor, «Polska Bibliografia Bibliologiczna» jako źródło do dziejów książki i biblioteki jasnogórskiej, ABMK, 96 (2011) s. 5-22.

${ }^{53} \mathrm{~A}$. Sieńczak, Biblioteka bernardynów radomskich w świetle inwentarza z $1865 \mathrm{r}$., ABMK, 76 (2001) s. 269-285.

${ }^{54} \mathrm{~K}$. Sitnik, Księgozbiór konwentu we Lwowie odzwierciedleniem zainteresowań intelektualnych bernardynów lwowskich II pot. XV-XVIII wieku, ABMK 81 (2004) s. 225-252.

${ }^{55}$ M. Szczotka, Trzynastowieczny graduat MS. 205 z Biblioteki Klarysek krakowskich w'świetle polskiej i europejskiej tradycji liturgiczno-muzycznej. Studium źródtoznawcze, cz. 1, ABMK, 71 (1999) s. 253-368; cz. 2, ABMK 72 (1999) s. 353-443.

${ }^{56}$ T. Bratkowski, Antyfonarz «De tempore» MS 1-4 z klasztoru benedyktynek w Staniatkach, ABMK, 93 (2010), s. 5-67.

${ }^{57}$ U. Kopeć-Zaborniak, Dzieje księgozbiorów średniowiecznych bibliotek benedyktyńskich, ABMK, 90 (2008), s. 74-89.

${ }^{58}$ J. Rudnicka, Zagadnienie opracowania dawnych ksiązek $w$ polskich zbiorach kościelnych oraz sposoby ich zabezpieczenia, ABMK, 56 (1988) s. 177-182; W. S z e n k, W jaki sposób można ustalić czas powstania oraz miejsce pochodzenia i używania śląskich rękopisów liturgicznych? ABMK, 21 (1970) s. 33-54; J. Wasilewska, O potrzebie ochrony zbiorów bibliotecznych, ABMK, 87(2007) s. 275-280; U. Szymańska, Kopia Czu oryginat? Problemy wspótczesnej biblioteki, ABMK, 91 (2009) s. 279-289; B. Warząchowska, Biblioteki klasztorne na tamach «Naszej Przeszłości». Zarys problematyki, ABMK, 96 (2011) s. 195-208.

${ }^{59}$ A. Jastrzębski, Pierwszy kurs bibliotekarski OO Kapucynów Prowincji Warszawskiej, ABMK 4 (1962) s. 353-355; B. Kumor, Sprawozdanie z kursu dla pracowników inwentaryzacji średniowiecznych rękopisów bibliotecznych, zorganizowanego przez Ośrodek Archiwów, Bibliotek i Muzeów Kościelnych $w$ dniach od 4 do 8 lipca 1960, ABMK, 2 (1961) z. 1/2, s. 283-288.

${ }^{60}$ B. Kumor, Katalog mikrofilmów Ośrodka Archiwów, Bibliotek i Muzeów Kościelnych przy Katolickim Uniwersytecie Lubelskim. Nr 1, ABMK, 6 (1963) s. 67-153; tenże, Katalog mikrofilmów Ośrodka Archiwów, Bibliotek i Muzeów Kościelnych przy Katolickim Uniwersytecie Lubelskim. Nr 2, ABMK, 13 (1966) s. 171-268; tenże, Katalog mikrofilmów Ośrodka Archiwów, Bibliotek i Muzeów Kościelnych przy Katolickim Uniwersytecie Lubelskim. Nr 3, ABMK, 24 (1972) s. 173-277; tenże, Katalog Mikrofilmów Ośrodka Archiwów, Bibliotek i Muzeów Kościelnych przy Katolickim Uniwer- 
w 84 tomie $\mathrm{ABMK}^{61}$. W przygotowaniu jest wydanie całościowego katalogu mikrofilmoteki Ośrodka ABMK w postaci samoistnej publikacji.

Ośrodek Archiwów Bibliotek i Muzeów Kościelnych Katolickiego Uniwersytetu Lubelskiego Jan Pawła II wypełnia w miarę swych możliwości powierzone mu zadanie, w zakresie dokumentowania zbiorów kulturowych Kościoła katolickiego w Polsce. Niestety dokumentacja księgozbiorów klasztornych nie jest satysfakcjonująca. Jednak nawet te nielicznie opracowane i zmikrofilmowane klasztorne zbiory biblioteczne są ważnym wkładem Ośrodka ABMK w zachowanie i udostępnianie szerokiemu gronu badaczy zbiorów kulturowych Kościoła katolickiego w Polsce.

\section{WORK OF THE CENTRE FOR CHURCH ARCHIVES LIBRARIES AND MUSEUMS IN DOCUMENTING THE COLLECTIONS OF MONASTIC LIBRARIES}

\section{Summary}

One of the statutory tasks of the Centre for Church Archives Libraries and Museums is to gather and organise materials of Church provenance. The most valuable materials are microfilmed and digitized in the documentary studio. So far, the most important materials from the below mentioned libraries have been microfilmed in the Centre for Church Archives Libraries and Museums: the Pauline Fathers' library in Jasna Góra, the Cistercians' library in Mogilno, the Carmelite Nuns' library in Crakow, the Poor Clares' library in Stary Sącz and Crakow, the Visitandines' library in Crakow, the Benedictine monks' library in Tyniec and the Benedictine nuns' library in Przemyśl and Staniątki, the library of Equestrian Order of the Holy Sepulchre of Jerusalem in Miechów and the Norbertine Sisters' library in Imbramowice.

The Centre for Church Archives Libraries and Museums also organizes symposia on book collections of the Church. Reports and papers delivered in symposia are printed in a semi-annual magazine „Church Archives Libraries and Museums." The magazine also contains the catalogues of monastic libraries and monographs on individual libraries.

Translated by Aneta Kiper

sytecie Lubelskim. Nr 4, ABMK, 31 (1975) s. 283-380; J. Kania, Katalog mikrofilmów Ośrodka Archiwów, Bibliotek i Muzeów Kościelnych przy Katolickim Uniwersytecie Lubelskim. Nr 5, ABMK, 51 (1985) s. 5-115; M. Dębowska, Katalog mikrofilmów Ośrodka Archiwów, Bibliotek i Muzeów Kościelnych przy Katolickim Uniwersytecie Lubelskim. Nr 6, ABMK, 67 (1997) s. 143-220.

${ }^{61}$ M. Dębowska, Katalog mikrofilmów Ośrodka Archiwów Bibliotek i Muzeów Kościelnych Katolickiego Uniwersytetu Lubelskiego. Nr 7, ABMK, 84 (2005) s.5-72. 